(С) А.И. Бураев

\title{
ПАМЯТИ УЧИТЕЛЯ. АНТРОПОЛОГИЧЕСКИЕ ИССЛЕДОВАНИЯ ЦИРКУМБАЙКАЛЬЯ В ТРУДАХ И.И. ГОХМАНА*
}

\begin{abstract}
Статья посвящена памяти выдающегося советского и российского антрополога Ильи Иосифовича Гохмана. Констатирован широкий круг научных интересов исследователя. В сообщении рассмотрен региональньй аспект деятельности ученого. Проанализировань работы И.И. Гохмана по антропологии населения Прибайкалья и Забайкалья. Ученый внес значительный вклад в изучение краниологии эпохи неолита, основываясь на материалах Фофановского могильника из Забайкалья. И.И. Гохман дал полную антропологическую характеристику и историческую интерпретацию краниологических данных по населению культуры плиточных могил бронзового века. Вылеляются исследования им населения эпохи хунну, в которых была впервые зафиксирована европеоидная примесь у древнего населения Байкальской Сибири, впоследствии подтвержденная в совместной фундаментальной монографии В.П. Алексеева и И.И. Гохмана. В статье проанализировань работы И.И. Гохмана по антропологическим материалам средневековых могильников Улан-Бор и Усть-Талькин в Прибайкалье. Особое место занимает концепџия И.И. Гохмана о формировании цчентральноазиатской расы в результате метисации байкальской расы с европеоидами. Отдельно упомянута выдающаяся работа И.И. Гохмана «Происхождение иеентральноазиатской расы в свете новых палеоантропологических материалов». В ней ученым были введены новые краниологические индексы, дан новаторский анализ материала, изложена новая теоретическая концепџия. И.И. Гохман ввел в научный оборот новые уникальные краниологические материаль, предложил новые теоретические разработки, в корне изменившие представления об антропологических процессах на территории Прибайкалья и Забайкалья. Работь И.И. Гохмана вызвали плодотворную дискуссию среди специиалистов и дали импульс новым исследованиям по антропологии Байкальской Сибири.
\end{abstract}

Ключевые слова: антропология, краниология, центральноазиатская раса, Байкальская Сибирь, Прибайкалье, Забайкалье

Выдающийся советский и российский антрополог Илья Иосифович Гохман был не только научным руководителем, но и Учителем с большой буквы для автора настоящей статьи. Разумеется, у него было много учеников, но мне выпала честь быть одним из последних.

Бураев Алексей Игнатьевич - к.и.н., научный сотрудник Отдела истории и культуры Центральной Азии, Институт монголоведения, буддологии и тибетологии Сибирского отделения РАН. (670047, Улан-Удэ, ул. Сахьяновой, 6. Россия). Эл. почта: buraev 1961@mail.ru

* Статья подготовлена в рамках государственного задания (проект XII.191.1.2). Межкультурное взаимодействие, этнические и социально-политические процессы в Центральной Азии, № AAAA-A17-117021310264-4 (Intercultural relationships, ethnic and sociopolitical processes in Central Asia) 
Круг научных интересов ученого был чрезвычайно широк. Однако, по нашему мнению, одной из главных заслуг И.И. Гохмана является сохранение российской краниологической школы. Его работы в области краниологии охватывают огромную территорию. Но предлагаемая работа, в силу собственной компетенции автора, носит подчеркнуто региональный характер.

Рассматриваемый регион в классических работах советского периода объединял две связанные озером Байкал территории: Прибайкалье и Забайкалье. В последние десятилетия для него очень часто используется термин «Байкальская Сибирь». Автор когда-то предлагал закрепить за этой территорией наименование «Циркумбайкалье», но название не прижилось. В этой связи, в статье будут использоваться все три названия, относящиеся к одному региону. Отметим, что Байкальская Сибирь - территория крайне интересная для изучения процессов расогенеза (на уровне малых рас) и этногенеза, что определяется чрезвычайно высокой динамикой населения региона. Действительно охотники эпохи неолита совершали рейды на довольно значительные расстояния от Приангарья до центральной Монголии, что зафиксировано археологически. В дальнейшем от эпохи бронзы до этнографической современности Байкальскую Сибирь населяли кочевники, которые, как известно, могли достаточно быстро перемещаться еще более масштабно. Кроме того, из письменных источников известно, что кочевые племена меняли свое название в пользу господствующего в центральноазиатских степях объединения (Таскин 1984: 45, 297-298) и, зачастую, просто вливались в него. Тем более, что территория с древнейших времен была довольно густо заселена. Поэтому неудивительно, что антропологи, в том числе и И.И. Гохман, достаточно давно обратились к изучению древнего и средневекового населения региона.

Нельзя не отметить, что регион исследовали и представители смежных гуманитарных наук. Так, письменные источники сохранили для потомков наименования многих племен, проделана значительная и нужная работа по сопоставлению китайских и тюркских источников с целью идентификации разных названий одного и того же племени. Археологам убедительно удалось идентифицировать часть племен с открытыми археологическими культурами. Во многих случаях определены происхождение, направление связей с соседями и миграционных потоков, дальнейшая историческая судьба племен и племенных объединений.

Все эти результаты были бы невозможны без привлечения данных палеоантропологии. Действительно, материальные традиции и даже название какого-либо народа могут передаваться без генетических контактов их носителей. Таким примерам в истории человечества «несть числа». В то же время, смена антропологического состава, безусловно, свидетельствует о появлении здесь нового населения. Таким образом, задача определения степени метисации или полной смены антропологического состава, в связи с особой динамичностью охотничьих и кочевых объединений, приобретает для рассматриваемой территории первостепенное значение.

Говоря об И.И. Гохмане, было бы неправильно не упомянуть других исследователей антропологического состава Циркумбайкалья. Начало изучению байкальского региона было положено в конце XIX в. Ю.Д. Талько-Грынцевичем, возглавлявшим Троицкосавско-Кяхтинское отделение Приамурского отдела Русского географического общества. Роль и значение работ Ю.Д. Талько-Грынцевича были всесторонне оценены в статье И.И. Гохмана «Антропологическое изучение Забайкалья в Троицко-Кяхтинском отделении Русского географического общества» (Гохман 1977). Тем самым был дан достойный пример отношения современных исследователей к своим предшественникам. 
В дальнейшем свой вклад в антропологию циркумбайкальского региона внесли Г.Ф. Дебец, М.Г. Левин, М.М. Герасимов, И.М. Золотарева, Н.Н. Мамонова, М.М. Герасимова. Исследователями были введены в научный оборот репрезентативные антропологические материалы, дана историческая и расогенетическая интерпретация полученных данных.

Еще раз отметим особую роль Ильи Иосифовича Гохмана в антропологическом изучении Прибайкалья и Забайкалья. В 1954 г. выходит его первая работа, основанная на забайкальских материалах (в основном из Фофановского могильника), составивших небольшую серию из 8 черепов (Гохман 1954). В ней исследователь отметил антропологическую однородность серии, ее принадлежность к монголоидной расе и, более конкретно, к локальному варианту палеосибирской расы, распространенной в неолитическое время на территории Прибайкалья. Тем самым, автор включился в полемику о происхождении антропологических особенностей неолитического населения Прибайкалья, заключавшихся в некотором ослаблении монголоидного комплекса признаков по сравнению с другими древними и современными монголоидными группами региона. Собственно, обе точки зрения на указанную проблему были высказаны Г.Ф. Дебецем. В своих ранних работах по этой проблематике он указывал на несомненное наличие европеоидной примеси у неолитического населения Прибайкалья (Дебец 1930; Дебец 1948). Позднее, им же была обоснована прямо противоположная гипотеза о протоморфном монголоидном типе у неолитических племен Прибайкалья, характеризующимся сочетанием монголоидных и европеоидных особенностей. Разрешение этого вопроса Дебец поставил в зависимость от степени выраженности монголоидного комплекса признаков к востоку и северо- востоку от Прибайкалья (Дебец 1951).

Наиболее аргументировано против гипотезы о протоморфном недифференцированном типе неолитического населения Прибайкалья выступил М.Г. Левин (Левин 1958). Им были проанализированы все известные к тому времени черепа эпохи неолита с территории, лежащей к востоку и северо-востоку от Байкала, и сделан вывод о их несомненной монголоидности, что, в свою очередь, косвенно свидетельствовало о европеоидной примеси у неолитического населения Прибайкалья (Левин 1958: 157-163).

Во многом точка зрения М.Г. Левина, остающаяся наиболее аргументированной и по сей день, основана на материалах из Фофановского могильника, опубликованных И.И. Гохманом.

И.И. Гохман, пересмотрев свои взгляды на принадлежность черепов из Фофаново к локальному варианту палеосибирской расы (Гохман 1958), пошел значительно дальше, признав неоднородность неолитического населения Забайкалья, которое ранее представлялось гомогенной общностью (Гохман 1977: 159; Гохман 1980: 20). В статье 1980 г. им, в качестве гипотезы, были реконструированы исходные компоненты населения Забайкалья эпохи неолита: долихокранный европеоидный тип и мезо- или брахикранный, с резко уплощенным лицом (Байкальская раса) (Гохман 1980: 22). При этом само неолитическое население, по мнению автора, «не уступает по выраженности монголоидных признаков краниологическим сериям современных сибирских монголоидов» (Алексеев, Гохман 1984: 33).

Интерес исследователя к Байкальской Сибири не ограничился эпохой камня. В последующие ей эпохи бронзы и раннего железа здесь проживало население, оставившее памятники культуры плиточных могил. Первым исследователем антропологии населения культуры плиточных могил был так же Ю.Д. Талько-Грынцевич (Талько-Грынцевич 1906), но впервые полная антропологическая характеристика и историческая 
интерпретация антропологических данных по населению культуры плиточных могил даны И.И. Гохманом (Гохман 1958; Гохман 1967; Гохман 1980). Им были отмечены генетическая преемственность между населением эпохи неолита и позднего бронзового века Забайкалья и несомненное участие последних в этнических процессах в регионе в гуннскую и последующие эпохи. Отметим, что, несмотря на малочисленность данной серии, краниологический материал из плиточных могил однороден и весьма выразителен. Поэтому нельзя не согласиться с И.И. Гохманом в том, что «на протяжении эпохи бронзы в Забайкалье формируется и концу ее уже складывается довольно однородный... антропологический тип, отличающий население Забайкалья от населения соседних территорий» (Гохман 1967). В систематическом плане исследователь отнес черепа из плиточных могил к байкальской расе.

В конце I тыс. до н.э. население культуры плиточных могил в степных районах Западного Забайкалья сменяют племена хунну. Их погребальные памятники были открыты и исследованы археологическими и антропологическими методами Ю.Д. Талько-Грынцевичем в 1896-1897 гг. (Талько-Грынцевич 1898-1900; Талько-Грыниевич 1905; Талько-Грынщевич 1928). В дальнейшем антропологические материалы хунну изучались Г.Ф. Дебецем и Н.Н. Мамоновой (Дебец 1948; Мамонова 1974). Исследователи идентифицировали полученные материалы с хунну, констатировали их монголоидность, не исключая наличия небольшой европеоидной примеси, связываемой с неолитическим населением Прибайкалья. Особое внимание в краниологической характеристике привлекла мезокрания хуннской серии, резко выделяющая их на фоне брахикраниого населения региона. Исходя из этого факта, Г.Ф. Дебец предположил, что хунну Забайкалья не являются прямыми потомками населения предшествующей стадии, имея ввиду брахикранное население эпохи неолита и черепа из херексуров (Дебеи 1948: 123).

И.И. Гохман, подтвердив вывод Г.Ф. Дебеца об отсутствии генетической преемственности между хунну и их предшественниками на территории Забайкалья, и распространив его на носителей культуры плиточных могил в посвященной последним статье (Гохман 1958: 441), в дальнейшем усомнился в приходе хунну с другой территории (Гохман 1980: 29). К этому времени в распоряжении исследователя находился значительно больший по численности материал, расширилась география находок (Иволгинское городище) (Гохман, 1969: 166-173), кардинально изменилась даже расовая характеристика отдельных черепов. В работе 1977 г. автор прямо указывает: «Любой способ внутригруппового анализа серии хуннов Забайкалья показывает наличие в ней морфологически противоположных вариантов. В серии преобладают монголоидные черепа байкальского типа. Но наряду с ними имеются и совершенно европеоидные черепа с резко профилированным лицом, высоким переносьем, сильно выступающими носовыми костями» (Гохман 1977: 162-163). Новые данные позволили И.И. Гохману предположить, что один из компонентов, входящий в состав хунну, происходит от населения культуры плиточных могил. Другой, европеоидный - от западных соседей, однако и этими компонентами не исчерпывается антропологический состав хуннской серии. В фундаментальной монографии В.П. Алексеева и И.И. Гохмана «Антропология азиатской части СССР», авторы предположили и возможность небольшой примеси дальневосточной расы в антропологическом составе хунну. Там же была предложена версия о происхождении европеоидной составляющей в хуннской серии: «Что касается европеоидной примеси в составе хуннов, то она могла появиться либо в результате западных контактов непосредственно 
в скифскую или гуннскую эпоху, либо быть унаследованной от неолитического населения Прибайкалья» (Алексеев, Гохман 1984: 69).

Современный анализ материала позволяет сделать вывод о синхронном сосуществовании различных расовых типов на территории байкальского региона в хуннское время. По всей видимости, европеоиды, дальневосточные монголоиды и автохтонное население региона активно контактировали между собой на всем протяжении I тыс. до н.э. и в первые века н.э. Таким образом, байкальский регион являлся маргинальным для монголоидных и европеоидных популяций. (Бураев 2006: 40-84).

Общепризнано, что процесс формирования центральноазиатской расы (как представлялось ранее - выраженно монголоидной группы популяций) проходил на территории Циркумбайкалья. Современные народы центральноазиатской расы, проживающие на территории региона, зачастую представлялись едва ли не «образцом» монголоидности. В этой связи значительный интерес представляют антропологические материалы эпохи средневековья.

Открытие могильника Усть-Талькин в Прибайкалье (Седякина 1965: 196-202) значительно расширило представления об антропологии Байкальского региона. Впервые в распоряжении антрополога оказалась репрезентативная средневековая серия из одного, хронологически единого, могильника с территории Прибайкалья. Серию составляют 18 мужских и 12 женских черепов (Гохман 1963: 339). И.И. Гохман отметил выраженную однородность серии и ее несомненное сходство с сериями центральноазиатского антропологического типа. Наибольшее сходство усть-талькинские черепа обнаруживают с черепами забайкальских бурят, которые являются, по мнению исследователя, их прямыми потомками. При этом особое внимание было уделено резко выраженной брахикрании изученной серии. Именно эта черта в краниологической характеристике усть-талькинцев позволила И.И. Гохману предположить их связь с носителями культуры плиточных могил Забайкалья. Таким образом, обнаруживая сходство, как с древним, так и с современным населением региона, усть-талькинцы, согласно автору, имеют самое прямое отношение к формированию центральноазиатской расы. Поставив вопрос о наличии европеоидной примеси у усть-талькинцев, основываясь на их сходстве по некоторым признакам с енисейскими кыргызами, И.И. Гохман ответил на него в принципе отрицательно, не исключив все же такую возможность окончательно (Гохман 1963: 338-359).

В 1968 г. была опубликована статья И.И. Гохмана по антропологическим материалам, полученным при раскопках А.П. Окладникова на городище Улан-Бор (Окладников 1963: 273-281). Они неопровержимо свидетельствуют о проживании в Прибайкалье в VIII-IX вв. европеоидов памиро- ферганского облика (Гохман 1968: 108-126). Хронология и антропологическая характеристика серии не вызывает сомнения. На основании своих исследований, данных письменных источников и археологии, И.И. Гохман отнес эту группу населения к средневековым согдийцам (Гохман 1968: 124). Полученные данные позволили связать средневековое население с бурятской группой «сартул» и предположить возможность европеоидной примеси у последних (Гохман 1968: 125).

Улан-Борская серия глубоко повлияла на представления об антропологическом составе населения региона. Связи с ираноязычным миром стали реальностью. В то же время возник другой вопрос - сыграл ли этот компонент значительную роль в дальнейшей истории населения Байкальского региона? Небольшая численность черепов памиро-ферганского облика и значительная трудность определения европе- 
оидного компонента в составе населения Прибайкалья и Забайкалья затрудняют ответ. И все же, создается впечатление, что влияние памиро-ферганского компонента на формирование складывающейся антропологической общности было либо крайне незначительным, либо отсутствовало вовсе (Бураев 2000: 72). Черепа из Улан-Бора отличаются от классических монголоидов кардинально. Кроме выраженной европеоидности бросается в глаза их грацильность, несвойственная антропологическому облику последующего населения региона.

Изучение антропологического состава древнего и средневекового населения региона позволило сделать вывод о наличии европеоидного влияния и, соответственно, возможности европеоидной примеси у современных центральноазиатских народов Прибайкалья и Забайкалья.

Формированию центральноазиатской расы посвящена выдающаяся по предложенным в ней подходам, новым методам и теоретической смелости автора, статья И.И. Гохмана «Происхождение центральноазиатской расы в свете новых палеоантропологических материалов» (Гохман 1980). Новаторский анализ материала и введение новых краниологических индексов (Гохман 1980: 7-8) позволили исследователю не только внести новые представления об антропологии Прибайкалья и Забайкалья, но и выдвинуть гипотезу о происхождении центральноазиатской расы.

И.И. Гохман предположил, что «...центральноазиатская раса сформировалась в результате метисации древней байкальской расы с европеоидами» (Гохман 1980: 33). В тоже время, автор отметил, что фактор метисации не был единственным фактором формирования центральноазиатской расы. На основе в основном средневековых материалов, автор настоящего сообщения поддерживает гипотезу о метисационном происхождении центральноазиатской расы (Бураев 2000: 95). Действительно, сложно предположить долговременное сосуществование европеоидов и монголоидов на территории Байкальского региона без генетических контактов, притом, что зачастую представители различных рас захоронены в одних могильниках по однотипному обряду.

Работая с антропологическими материалами из Байкальской Сибири мне, естественно, пришлось иметь дело с материалами и работами И.И. Гохмана. Его профессионализм, глубокое исследовательское чутье, пионерские идеи дали импульс для моих собственных исследований. Основные положения настоящей статьи впервые были изложены в докладе на международной научной конференции «Проблемы изучения изменчивости в антропологии. Новое в многообразии традиционного» 16 мая 2019 г.

И.И. Гохман внес выдающийся вклад в антропологическое изучение Прибайкалья и Забайкалья. Им введены в научный оборот новые уникальные материалы, позволившие изменить представление об антропологических процессах на этой территории. Теоретические разработки И.И. Гохмана вызвали плодотворные дискуссии среди ученых и привели к новым исследованиям по антропологии Байкальской Сибири.

\section{Научная литература}

Алексеев В.П., Гохман И.И. Антропология азиатской части СССР. М.: Наука. 1984.

Бураев А.И. Средневековое население Прибайкалья и Забайкалья по данным краниологии.

Улан-Удэ: Изд-во Бурятского научного центра СО РАН. 2000.

Бураев А.И. Антропология Прибайкалья и Забайкалья (древность и средневековье). Улан-Удэ: Изд-во Бурятского научного центра СО РАН. 2006.

Гохман И.И. Материалы по антропологии древнего населения низовьев Селенги // Краткие 
сообщения Института этнографии АН СССР. М.; Л., 1954. Вып. ХХ. С. 59-67.

Гохман И.И. Антропологические материалы из плиточных могил Забайкалья // Сборник музея антропологии и этнографии АН СССР. М.; Л., 1958. Т.8. С. 428-443.

Гохман И.И. Палеоантропологические материалы из могильника Усть-Талькин в Прибайкалье // Сборник Музея антропологии и этнографии АН СССР. М.; Л., 1963. Т.21. С. 338-359.

Гохман И.И. К вопросу об антропологических особенностях древних скотоводов в Забайкалье // Советская этнография, 1967. № 6. С. 95-100.

Гохман И.И. Среднеазиатская колония в Прибайкалье // Проблемы антропологии и исторической этнографии Азии. М., 1968. С. 108-126.

Гохман И.И. Антропологическая характеристика черепов из Иволгинского городища // Труды Бурятского комплексного научно- исследовательского института. Улан-Удэ, 1969. Вып. 3. С. 66-173.

Гохман И.И. Антропологическое изучение Забайкалья в Троицко-Кяхтинском отделении Русского географического общества // Очерки истории русской этнографии, фольклористики и антропологии. Л., 1977. Вып.7. С. 158-164.

Гохман И.И. Происхождение центральноазиатской расы в свете новых палеоантропологических материалов // Исследования по палеоантропологии и краниологии СССР. Сборник Музея антропологии и этнографии АН СССР. Л., 1980. Т.36. С. 5-34.

Дебеи Г.Ф. Антропологический состав населения Прибайкалья в эпоху позднего неолита // Русский антропологический журнал, 1930. Т. ХІХ. Вып. 1-2. С. 7-50.

Дебеи Г.Ф. Палеоантропология СССР. (Труды института этнографии АН СССР; Т.4). М.; Л., 1948. Дебеи Г.Ф. Антропологические исследования в Камчатской области. Труды Института этнографии СССР. М., 1951. Т.17.

Левин М.Г. Этническая антропология и проблемы этногенеза народов Дальнего Востока. Труды Института этнографии АН СССР. М., 1958. Т.36.

Мамонова Н.Н. К антропологии гуннов Забайкалья (По материалам могильника Черемуховая падь) // Расогенетические проблемы в этнической истории. М., 1974. С. 201-228.

Окладников А.П. Новые данные по истории Прибайкалья в тюркское время // Тюркологические исследования. М.; Л., 1963. С. 273-281.

Седякина Е.Ф. Могильник Усть-Талькин // Труды Бурятского Комплексного научно-исследовательского института СО АН СССР. Улан-Удэ, 1965. Вып.16. С. 196-202.

Талько-Грынцевич Ю.Д. Материалы к палеоэтнологии Забайкалья. III // Труды Троицкосавско-Кяхтинского отделения Приамурского отдела Русского географического общества. М., 1898-1900. Т. 1. Вып. 3. С. 35-76.

Талько-Грынцевич Ю.Д. Древние аборигены Забайкалья в сравнении с современными инородцами. Сравнительно-антропологический очерк // Труды Троицкосавско-Кяхтинского отделения Приамурского отдела Русского географического общества. СПб, 1905. Т. 8. Вып. 1. С. 32-51.

Талько-Грынцевич Ю.Д. Население древних могил и кладбищ забайкальских // Бурятиеведение. Верхнеудинск, 1928. № 1-3 (5-7). С. 91-103.

Таскин В.С. Материалы по истории древних кочевых народов группы дунху. М.: Наука, 1984.

Buraev, Aleksey I.*

To the memory of the Teacher. Anthropological Studies of the Circum-Baikal region in the works of I.I. Gokhman

DOI: $10.33876 / 2311-0546 / 2020-52-4 / 249-257$

The article is dedicated to the memory of the outstanding Soviet and Russian anthropologist Ilya Iosifovich Gokhman, who had a wide range of scientific interests. The study examines the regional aspect of his research and analyzes his works on anthropology of population of Baikal and Trans-Baikal regions. Gokhman made a significant contribution to the study of craniology of the Neolithic, based on the materials of the Fofanovo burial site from Trans-Baikal. He made a 
complete anthropological description and historical interpretation of craniological data on the population of the Bronze Age slab graves culture. His outstanding research on the population of the Hunnu era first revealed the Caucasoid admixture among the ancient population of Baikal Siberia, which was later confirmed in a joint fundamental monography by V.P. Alekseev and I.I. Gokhman. The article also analyzes the work of Gokhman on anthropological materials of the medieval burial sites Ulan-Bor and Ust-Talkin in the Baikal region. Another important finding of the scientist is the concept of formation of the Central Asian race as a result of metisation between the Baikal race and the Caucasians. His remarkable paper "The origin of the Central Asian race in the light of new paleoanthropological data" is separately mentioned. In it, Gokhman introduced new craniological indices, made a comprehensive analysis of the material and presented a new theoretical concept. He introduced new unique craniological materials, proposed new theoretical developments that fundamentally changed ideas about anthropological processes on the territory of Baikal and Trans-Baikal regions. The works of I.I. Gokhman provoked insightful debate among experts and gave impulse to new research on anthropology of Baikal Siberia.

Key words: anthropology; craniology; Central Asian race; Baikal Siberia; Baikal region; Trans-Baikal region

* Buraev Aleksey I. - Institute for Mongolian, Buddhist and Tibetan Studies of the Siberian Branch of the Russian Academy of Sciences (IMBTS SB RAS), Department of History and Culture of Central Asia (Sakhianovoi str, 6, Ulan-Ude, Russia). E. mail: buraev1961@mail.ru

\section{References}

Alekseev, V.P., I.I. Gokhman. 1984. Antropologiya aziatskoi chasti SSSR [Anthropology of the Asian part of the USSR]. Moscow: Nauka.

Buraev, A.I. 2000. Srednevekovoe naselenie Pribaikal'ya i Zabaikal'ya po dannym kraniologii [Medieval population of the Baikal region and Transbaikalia according to craniology data]. Ulan-Ude: Izdatel'stvo Buryatskogo nauchnogo tsentra SO RAN.

Buraev, A.I. 2006. Antropologiya Pribaikal'ya i Zabaikal'ya (drevnost'i srednevekov'e) [Anthropology of the Pribaikalia and Transbaikalia (antiquity and the Middle Ages)]. Ulan-Ude: Izdatel'stvo Buryatskogo nauchnogo tsentra SO RAN.

Gokhman, I.I. 1954. Materialy po antropologii drevnego naseleniya nizov'ev Selengi [Materials on the anthropology of the ancient population of the lower reaches of the Selenga]. In Kratkie soobshcheniia Instituta etnografii AN SSSR [Brief reports of the Institute of Ethnography of the USSR Academy of Sciences]. Iss. XX: 59-67. Moscow; Leningrad.

Gokhman, I.I. 1958. Antropologicheskie materialy iz plitochnykh mogil Zabaikal'ia [Anthropological materials from the slab graves of Transbaikalia]. In Sbornik muzeya antropologii i etnografii AN SSSR [Collection of the Museum of Anthropology and Ethnography of the USSR Academy of Sciences] 8: 428-443. Moscow; Leningrad.

Gokhman, I.I. 1963. Paleoantropologicheskie materialy iz mogil'nika Ust'-Tal'kin v Pribaikal'e [Paleoanthropological materials from the Ust' -Talkin burial ground in the Pribaikalie]. In Sbornik Muzeia antropologii i etnografii AN SSSR. [Collection of the Museum of Anthropology and Ethnography of the USSR Academy of Sciences] 21: 338-359. Moscow; Leningrad.

Gokhman, I.I. 1967. K voprosu ob antropologicheskikh osobennostyakh drevnikh skotovodov v Zabaikal'e [On the question of the anthropological characteristics of the ancient nomads of Transbaikalia]. Sovetskaia etnografiia 6: 95-100.

Gokhman, I.I. 1968. Sredneaziatskaia koloniia v Pribaikal'e [Central Asian colony in the Pribaikalie]. In Problemy antropologii i istoricheskoi etnografii Azii [Problems of Anthropology and Historical Ethnography of Asia] edited by V.P. Alekseev and I.S. Gurich, 108-126. Moscow: Nauka. 
Gokhman, I.I. 1969. Antropologicheskaia kharakteristika cherepov iz Ivolginskogo gorodishcha [Anthropological characteristics of skulls from the Ivolginsky settlement]. In Trudy Buriatskogo kompleksnogo nauchno- issledovatel'skogo instituta [Works of the Buryat Integrated Research Institute]. Iss. 3: 166-I73. Ulan-Ude.

Gokhman, I.I. 1977. Antropologicheskoe izuchenie Zabaikal'ia v Troitsko-Kiakhtinskom otdelenii Russkogo geograficheskogo obshchestva [Anthropological study of Transbaikalie at the Troitsko-Kyakhta branch of the Russian Geographical Society]. In Ocherki istorii russkoi etnografii, fol'kloristiki $i$ antropologii [Essays on the history of Russian ethnography, folklore and anthropology] edited A.M. Reshetov and T.V. Stanyukovich, 7: 158-164. Leningrad: Nauka.

Gokhman, I.I. 1980. Proiskhozhdenie tsentral'noaziatskoi rasy v svete novykh paleoantropologicheskikh materialov [The origin of the Central Asian race in the light of new paleoanthropological materials]. In Issledovaniia po paleoantropologii i kraniologii SSSR. Sbornik Muzeia antropologii i etnografii AN SSSR [Research in paleoanthropology and craniology of the USSR. Collection of the Museum of Anthropology and Ethnography of the USSR Academy of Sciences] edited by I.I. Gokhman, Leningrad: Nauka, 36: 5-34.

Debets, G.F. 1930. Antropologicheskii sostav naseleniia Pribaikal ' ia v epokhu pozdnego neolita. In Russkii antropologicheskii zhurnal, Vol. XIX. Iss. 1-2: 7-50.

Debets, G.F. 1948. Paleoantropologiia SSSR [Paleoanthropology of the USSR]. Moscow-Leningrad.

Debets, G.F. 1951. Antropologicheskie issledovaniia v Kamchatskoi oblasti [Paleoanthropological research in the Kamchatka region]. Leningrad: Izdatel'stvo Akademii nauk SSSR.

Levin M.G. 1958. Etnicheskaia antropologiia i problemy etnogeneza narodov Dal'nego Vostoka. In Trudy Instituta etnografii AN SSSR [Works of the Institute of Ethnography of the USSR Academy of Sciences] 36: 59-67. Moscow.

Mamonova, N.N. 1974. K antropologii gunnov Zabaikal'ia (Po materialam mogil'nika Cheremukhovaia pad') [On the anthropology of the Huns of Transbaikalia (Based on materials from the Cheryomukhovaya Pad 'burial ground)]. In Rasogeneticheskie problemy v etnicheskoi istorii [Race-genetic problems in ethnic history] edited by I.M. Zolotareva, 201-228. Moscow: Nauka.

Okladnikov, A.P. 1963. Novye dannye po istorii Pribaikal'ia v tiurkskoe vremia [New data on the history of the Baikal region in Turkic time]. In Tiurkologicheskie issledovaniia [Turkological research] edited by A.K. Borovkov, 273-281. Leningrad: Izdatel'stvo Akademii nauk SSSR

Sediakina, E.F. 1965. Mogil'nik Ust'-Tal'kin [Ust-Talkin burial ground]. In Trudy Buriatskogo Kompleksnogo nauchno-issledovatel'skogo instituta SO AN SSSR [Works of the Buryat Integrated Research Institute]. 16: 196-202. Ulan-Ude.

Tal'ko-Gryntsevich, Yu.D. 1898-1900. Materialy k paleoetnologii Zabaikal'ia [Materials for paleoethnology of Transbaikalia]. III. In Trudy Troitskosavsko-Kiakhtinskogo otdeleniia Priamurskogo otdela Russkogo geograficheskogo obshchestva [Works of the Troitskosavsko-Kyakhtinsky branch of the Amur branch of the Russian Geographical Society]. Vol. 1. Iss. 3: 35-76. Moscow.

Tal'ko-Gryntsevich, Yu.D. 1905. Drevnie aborigeny Zabaikal'ia v sravnenii s sovremennymi inorodtsami. Sravnitel'no-antropologicheskii ocherk [Ancient Aborigines of Transbaikalia in Comparison with Modern Foreigners. Comparative anthropological essay]. In Trudy Troitskosavsko-Kiakhtinskogo otdeleniia Priamurskogo otdela Russkogo geograficheskogo obshchestva [Works of the Troitskosavsko-Kyakhtinsky branch of the Amur branch of the Russian Geographical Society]. Vol. 8. Iss.1: 32-51. St.Petersburg.

Tal'ko-Gryntsevich Yu.D. 1928. Naselenie drevnikh mogil i kladbishch zabaikal'skikh [The population of the ancient graves and cemeteries of the Trans-Baikal]. In Buriatievedenie, Verkhneudinsk: 1-3 (5-7): 91-103.

Taskin, V.S. 1984. Materialy po istorii drevnikh kochevykh narodov gruppy dunkhu [Materials on the history of the ancient nomadic peoples of the Dunhu group]. Moscow: Nauka. 